\title{
Towards an understanding of the relationship between professional and employing organization
}

\author{
A.B. Boshoff \\ Graduate School of Management, University of Pretoria, Pretoria
}

This paper was written while the author was attached to the Durham University Business School as Visiting Professor

The position of the professional employee vis-a-vis his/her employing organization is examined. The values adhered to in scientific endeavour and the characteristics of professional work are contrasted with the characteristics of organizational functioning. The primary value adhered to in science is seen as a search for truth resulting in a 'scientific approach'. The differences between conventional wisdom and science are presented. Professional work is seen as a human endeavour characterized by specialized knowledge, high standards of conduct and a search for autonomy of the professions themselves. This is seen to go hand in hand with commitment to their work and a highly developed sense of responsibility displayed by professional people. Organizations are seen as organisms which function in an imperfect manner. The negative effects of this on the people in the organization are noted. A fundamental conflict is seen to emerge between the between system of the professional employee and the demands made by organizations employing professional people. Thoughts are expressed on how this conflict can best be handled. Conflicting empirical findings on the subject are presented and discussed. Some possible explanations for the diversity of findings in this field are offered.

S. Afr. J. Bus. Mgmt 1980, 11: $16-20$

Die posisie van die professionele werknemer vis-à-vis die organisasie waar hy of sy in diens is, word ondersoek. Die waardes waaraan in die wetenskaplike werk gehou word en die eienskappe van professionele werk word gekontrasteer met die eienskappe van organisatoriese funksionering. Die primére waarde wat in wetenskapsbeoefening nagestrewe word, word gesien as 'n soeke na die waarheid, wat dan lei tot ' $n$ 'wetenskaplike benadering'. Die verskille tussen algemene kennis en wetenskap word gestel. Professionele werk word gesien as ' $n$ menslike aktiwiteit gekenmerk deur gespesialiseerde kennis, hoe gedragstandaarde en soeke na outonomie. Dit gaan gepaard met werkstoewyding en 'n hoe gevoel van verantwoordelikheid wat deur professionele mense openbaar word. Organisasies word gesien as organismes wat onvolmaak funksioneer. Die negatiewe effekte hiervan op die mense in die organisasie word gestel. 'n Fundamentele konflik word gesien tussen die waardestelsel van die professionele werknemers en die eise wat deur werkgewers aan hulle gestel word. Gedagtes word uitgespreek oor hoe die konflik ten beste hanteer kan word. Botsende empiriese bevindings oor die onderwerp word gestel en bespreek en moontlike verklarings vir die diversiteit van bevindings word aangebied.

S.Afr. Tydskr. Bedryfsl. 1980, 11: $16-20$
The situation of the professional under various guises (scientists, engineers, technical specialists of some kind or other) has received a great deal of attention during the last two decades. Perrow' ${ }^{1}$ calls this ' . . certainly the hottest single topic in the field of organizational analysis during the early 1960s'. Now that some of the fire has died down, further attention to the topic may be worthwhile.

The generalized picture emerging from the work in this area seems to be that the relationship between organizations and their professional employees is, more often than not, an uneasy one, characterized by feelings of constrained autonomy, pressure on professional integrity and role demands for which the professional job incumbent is ill prepared.

The purpose of this article is to examine the relationship between professional employee and organization. This is done in terms of the values adhered to in science and the characteristics of the professional role on the one hand, and the characteristics of organizations and organizational processes on the other hand, in order to understand and explain the problems involved.

\section{The values adhered to in science}

In order to understand the background against which professionals apply their knowledge it is necessary to pause at the values pursued in science and which must be kept in mind during scientific endeavour and use of scientific knowledge. This is necessary as professional roots are to be founded in science and the values of science therefore form the basis of the values of all the professions.

Shils ${ }^{2}$ sees science as a body of systematized knowledge gathered in a pluralistic society.

According to Parsons ${ }^{3}$ the dominant standard of science is that of objective, impartial truth. The search for truth is therefore uppermost in the minds of scientists.

Parsons further sees science as being integrated with a value system in such a way that many of the basic values with which it is associated (and which will determine its ends) are not arbitrary but inherent in the nature of science. Sarton ' makes a point related to Parsons' view about the nature of science when he says: 'The whole fabric of science seems thus to be growing like a tree; in both cases the dependence upon the environment is obvious enough, yet the main cause of growth - the growth
A.B. Boshoff

Graduate School of Management, University of Pretoria, Hillcrest, Pretoria 0083, South Africa 
pressure, the urge to grow - is inside the tree, not outside'. Sarton's view apparently pictures science as an important endeavour with an unique, inherent growth potential.

Apart from the fundamental values adhered to in science a 'scientific approach' can be discerned. According to Berelson and Steiner ${ }^{5}$ the following elements make up the 'scientific approach':

- The procedures are public, for example a scientific report contains a complete description of what was done so that other researchers can follow each step of the investigation.

- The definitions are precise. It is clearly stated which procedures were used, the variables which are measured are specified and the measuring methods set out.

o Data-collecting is objective. Bias in collecting and interpreting data is avoided and active steps are taken to ensure that objectivity and completeness of data collection are achieved.

- The findings must be replicable so that the results of an investigation can be tested by other scientists.

o The process is systematic and cumulative.

o The purposes are explanation, understanding and prediction.

This approach implies, among other things, a selfcorrecting action in scientific work, that is, errors are identified and corrected by new findings.

Luthans $^{6}$ summarizes the major differences between common sense and science as follows:

o Common sense is vague compared to scientific knowledge.

- Flagrant inconsistencies often appear in common sense knowledge, whereas the demand for logical consistency is a hallmark of science.

- Science systematically seeks to explain the events with which it deals; common sense ignores the need for explanation.

- The scientific method deliberately exposes claims to the critical evaluation of experimental analysis; the informal methods of common sense fail to test conclusions in any systematic fashion.

The cornerstones of scientific endeavour seem to be systematized knowledge, an abiding concern for truth, a self-correcting tendency and an inherent growth potential, without this being seen by the present author as the final word on the scientific approach.

\section{The characteristics of professions and profes- sional work}

A 'profession' according to Shepard' involves service or ministry rendered out of specialized knowledge, high standards of conduct and a kind of democracy as the means of social control over its members.

The key element of Shepard's conception of a profession seems to be specialized knowledge. If it were not for specialized knowledge, high standards of conduct would be largely irrelevant and there would be little or no need for social control, that is, professional ethics; anyone would be able to detect actions serving the professional's self-interest rather than the interests of high quality ser- vice to others. Without specialized knowledge there would also be no common denominator, attaching individual practitioners to each other.

Along with specialized knowledge, however, go two related concepts namely commitment and responsibility.

According to Kornhauser ' ${ }^{B}$ professional commitment is based on the belief that the development and exercise of expertise is worthy of the devotion of a lifetime and carries its own reward. Professional responsibility is based on the belief that the power conferred by expertise entails a fiduciary relationship to society'. These observations of Kornhauser point in the direction of fundamental professional norms concerning personal objectives and selfimposed constraints and are critical in establishing the interrelationship between a profession and its task environment.

Schein ${ }^{9}$ has a view which seems to be related to the concept of commitment. He sees the professional, among other things, as an individual engaged in a full-time occupation which provides his principal source of income. He further arrives at the conclusion that the ultimate intention of professionalization is the achievement of 'autonomy' which implies:

o 'knowing better what is good for the client than anyone else because of extended technical education and training

- subjecting one's decisions only to the review of colleagues and setting all one's standards pertaining to jurisdiction of the profession and entry into it through peer group associations ${ }^{19} \mathrm{pp}^{9-10}$.

Having looked at the characteristics of a profession it seems to be necessary to look at developments which are affecting the professions. Schein' outlines a great number of changes affecting the professions, some of which seem to be relevant to the present discussion.

- New work environments. Professionals are increasingly employed in a greater variety of organizations and are not in a strict sense working as autonomous professionals.

- New concepts are emerging about who the clients of professionals are. Entire organizations are increasingly acting as the purchasers of the services of professionals of various kinds. It is becoming necessary for professionals to accommodate themselves to the situation where they are dealing with multiple client systems and with projects in which conflict between parts of the client system is created.

- More knowledge brings with it more specialities and sub-specialities, i.e. more differentiation. This makes integration of newly developed knowledge both difficult and necessary. Increased specialization, incidentally, seems to bring with it the dangers of obsolescence and conflict between sub-specialities.

The last theme is one on which Thompson ${ }^{10}$ formulated a proposition on which attention will be focussed again later.

- The role of professionals may be changing or should be changing. Attention should possibly be focussed on working for what Schein ${ }^{9.25}$ calls 'the poor and the powerless'. 
Systematized knowledge, truth, an inherent growth potential and an ability for self-correction are therefore the hallmarks of science with the use of specialized knowledge, high standards of conduct, personal responsibility and longterm commitment to their area of professional endeavour characteristic of the functioning of professionals. It also seems clear that the roles and functioning of scientists are undergoing changes. Having adopted, and behaving according to, such basic principles the scientists, however, face a rather unsympathetic, practical, if not pragmatic, organizational world in which they must hold their own.

\section{The characteristics of organizations}

As scientists and professionals are working more and more in organizations, a brief look at the characteristics of organizations and the processes operating in organizations is necessary for the purposes of this paper.

Classical writers like Fayol, ${ }^{11}$ Gulick, $^{12}$ Urwick $^{13}$ and some modern counterparts like Koontz and O'Donnel ${ }^{14}$ tend tgo see the industrial business organization as a completely logical entity operating in a risky environment with full or nearly full knowledge of relevant information and according to prescribed rules. This does not seem to be congruent with the reality as described by Simon, ${ }^{15}$ March and Simon, ${ }^{16}$ Cyert and March, ${ }^{17}$ Thompson ${ }^{10}$ and others.

Cyert and March see organizational processes as having the following characteristics:

\section{Quasi - resolution of conflict}

Organizations are pictured as consisting of sub-units resulting in local instead of general rationality, being typical, that is, sub-units handle a limited set of problems and a limited set of goals. This is given consistence through the use of acceptable level decision rules and sequential attention to the goals of different coalitions or sub-units.

A somewhat similar formulation of organization decision making is given by March and Simon ${ }^{16}$ who indicate that organizations tend to 'satisfice' rather than 'optimize'. This indicates the same concept as acceptable decision rules.

\section{Avoidance of uncertainty}

Organizations constantly strive towards risk-avoidance by negotiating their environments so as to create situations where risk is limited by 'good business practice', budgeting systems and negotiated price structures.

\section{Problemistic search}

It seems as if in their search for solutions to problems organizations tend to limit their attention to the specific, immediate problem at hand. Planned, systematic scanning of the environment with a view to the development of longterm solutions to immediate problems seems to be the exception.

The search activities carried out by organizations are furthermore 'simple-minded' that is, it is limited to the environment of the perceived symptom or symptoms of the problem. The search activity is carried out in the immediate environment of the problem for the present, easily available alternative. This is expanded only if the pre- sent alternative solution very obviously does not solve the problem, until a solution is found which will apparently solve the immediate problem. This solution is then used until it no longer serves its purpose, that is, until the problem changes so that a new, but again limited, search is carried out.

To complicate matters, the search activity of organizations is also biased. This is caused by overspecific, unbalanced training in different parts of the organization. From this results conflict, which is seldom effectively resolved.

Simon ${ }^{15}$ addresses himself to the same organizational phenomenon when he describes organizational decision making as being in terms of 'bounded rationality'.

It seems as if the descriptions of organizational processes as given by these authors can be correlated with the views of Mintzberg ${ }^{18}$ about how managers function in organizations. This seems to be in sharp contrast with the classical view of managerial functioning. Mintzberg says that top managers typically:

o have to do a great amount of work at an unrelenting pace

o do work characterized by great variety, brevity and discontinuity

- give preference to verbal instead of written communications resulting in a very large percentage of total time being spent in meetings and interaction with other people

o give priority to matters that are current and topical and can be solved with short process decision making.

Thompson ${ }^{10}$ sees the organization as consisting of a number of coalitions. The objectives of the organization at a given point in time are the negotiated settlements of the currently dominant coalition of the organization whose members may be inside and outside the organization. This settlement is fixed only as long as the dominant coalition is stable and the task environment undisturbed. Potential for conflict within the dominant coalition increases with

o the variety of professions incorporated;

- more interdependence of members (and the areas they represent or control); and

o external forces requiring internal compromise on outcome preferences.

Thompson also proposed the idea of an inner circle in the dominant coalition making decisions for the organization, especially when power tends to be widely distributed in the organization. Under such circumstances even the dominant coalition is unable to make decisions and this function then in effect passes to an inner circle.

Argyris ${ }^{19}$ presents the thesis that the requirements of the formal organization and the needs of the mature employee are not in congruence. He presents empirical evidence for this thesis and indicates that frustration, conflict, failures and short time perspective are experienced by employees who may either leave the organization, or climb the employment ladder, or defend their self-concept and adapt through the use of defence mechanisms. Bennis ${ }^{20}$ comes up with the same fundamen- 
tal idea, that is, that the growth and development of people are stunted by the way organizations function and that bureaucratic organizations are fundamentally inhospitable environments for people. He further indicates that organizations adapt very slowly to changes in their environments.

And into this seething mass of human aspirations the professional enters - in search of autonomy, truth and ideal solutions amidst power struggles, compromises, coalition formation and sub-obtimal decision making in organizations which are slowly adapting to new demands and situations.

\section{The choices for the professional/scientist in the organization}

As a preface to discussing ways of reacting to organizational processes it may be appropriate to quote Bray ${ }^{21}$ on the suitability of one group of professionals, psychologists, entering organizations. He says, inter alia: 'It is my observation that most of the young men applying for jobs in industry as new Ph.D's . . . have very little conception of what goes on in industry and are in many cases illsuited to make a contribution to a business organization. If employed, they tend to suffer from anxiety on two fronts. The source of one anxiety is their traditional graduate training in psychology which makes them feel compelled to be rigorous empiricists, laboratory experimenters, frequent publishers and so forth. On the other hand, they seem terrified by the world into which they have come. They readily accept management's ideas about what is wrong with the organization. They too easily accept definitions of problems from others'.

It is not argued that Bray's perceptions are necessarily correct or that they can be applied to scientists other than psychologists working in organizations. Bray may, however, be giving an illustration of the results of inadequate preparation of professional people for life in organizations.

\section{Thoughts on coping behaviour of professionals}

Having examined the sources of some of the problems experienced by professionals in organizations some speculation on how professionals can cope and can be helped to cope with the situation, are offered.

- The scientist/professional can join into the organizational in-fighting, coalition formation, etc. To be successful he or she will have to fight more effectively and possibly, cunningly, than the other organizational members. They will, in terms of Thompson's ${ }^{10}$ analysis, have to identify and join the dominant coalition (and preferably become part of the 'inner circle') to be really effective in their individual contribution to decision making in the organization. How this is to be achieved and what the effect on their professional/scientific work and personal wellbeing in terms of self-concept, role perceptions and so on will be, may be interesting topics for field research.

- The scientists/professionals could strive to increase their influence by gaining more recognition for their expert power. This may be especially true in the case of behavioural scientists, such as psychologists. Everyone is an 'amateur psychologist' and knows all there is to know about understanding people and activating them (Luthans ${ }^{6}$ ). It is difficult to prove to the managing director how little he knows without losing a client or an employer.

One way in which behavioural scientists can improve their position is to use their purported knowledge and skills to play a mediating role in the modern firm. Communicating with consumers through advertising and bargaining with organized labour are two obvious areas where this role is manifested.

- It seems as if, whatever line of approach the professional/scientist decides to take in the organization, he or she will have to possess superior negotiation skills. This is an area in which a considerable body of knowledge is in existence (see, for instance, Rubin \& Brown ${ }^{22}$ ).

- If the present line of reasoning is correct it seems as if some thought should be given to the content of the training of scientists and professionals who are to work in organizations. Schein ${ }^{9}$ talks about the need for convergence among the various scientific disciplines in contrast to the divergence which has been a feature of academic organization up to now. It seems that convergence in the training of prospective scientists and professionals (who are likely to end up in organizations) in the form of training in a specific discipline plus training aimed at better understanding of, and more skill in handling the professional role in organizations, may well be advisable.

\section{Conclusion}

It seems as if an understanding of the problem of professionals and scientists working in organizations may be enhanced by, on the one hand, an understanding of the value of science and the way in which professionals prefer to work and, on the other hand, a clear perception of the way in which organizations function. The dangers of thinking exclusively in terms of the generalizations used in this paper should, however, be kept in mind. Perrow ${ }^{1}$ apparently sees no real problem for professionals or scientists in bureaucratic organizations. A picture somewhat different from the one presented in this paper is gained from the work of Cotgrove and Box, ${ }^{23}$ Sofer $^{24}$ and $\mathrm{Scott}^{25}$ and, to a lesser degree, from the work of Lansbury. ${ }^{26}$ The hypothesis is put forward that cultural and time factors are involved - American studies appear to provide different results from studies in other countries, and more differentiated findings are reported in later than in earlier studies. Another notion may well have some validity, that individual differences in "career anchors' as defined by Schein ${ }^{27}$ may account for differences in the outcomes of the interaction between professionals and organizations.

The implications of the analysis and conclusions in this paper appear to be that, inter alia, organization development work should take into account the factors involved in the relationship between professional and organization. The analysis points to the need to concentrate, if OD work is done with regard to the problem, on cultural 
change, rather than trying to work on symptoms of the problem. This may involve getting relevant individuals to define the present organizational culture, desirable changes and strategies to bring about these changes, rather than working directly on, for instance, intergroup relations in the organization. The suspicion is voiced that too often the symptoms of the problem are treated, without understanding the underlying dimensions and reasons for the problem.

\section{Acknowledgement}

Ideas received from Elza Hamblin, co-author of an earlier article in a related field, are gratefully acknowledged.

\section{Roferences}

1 PERrow, C. Complex organizations. A critical essay. Scott, Foresman \& Co.: Glenview, Illinois, 1972, p.55.

2 SHILS, E.A. The anatomy of a science. In: The sociology of science. (eds) Barber, B. \& Hirsch, W. Free Press of Glencoe: New York, 1962.

3 PARSONS, T. Some aspects of the relation between social science and ethics. In: The sociology of science. (eds) Barber, B. \& Hirsch, W. Free Press of Glencoe: New York, 1962.

4 SARTON, G. The history of science and the new humanism. Braziller: New York, 1956, p.177.

5 BERELSON, B. \& STEINER, G.A. Human behaviour: An inventory of scientific findings. Harcourt, Brace \& World: New York, 1964, pp. $16-17$.

6 LUTHANS, F. Organizational behavior. Second Edition, McGraw-Hill Kogakusha Ltd: Tokyo, 1977, p.42.

7 SHEPARD, H.A. Nine dilemmas in industrial research. In: The sociology of science. (eds) Barber, B. \& Hirsch, S. Free Press of Glencoe: New York, 1962.

8 KORNHAUSER, W. Scientists in industry, conflict and accommodation. Univ. of California Press: California, 1963, p.1.
9 SCHEIN, E.H. Professional Education: Some new directions. McGraw-Hill: New York, 1972.

10 THOMPSON, J.D. Organizations in action. McGraw-Hill: New York, 1967.

11 FAYOL, H. General and industrial management. Pitman \& Sons: London, 1949.

12 GULICK, L. Notes on the theory of organization. In: Papers on the science of administration, (eds) Gulick, L. \& Urwick, L. Inst. of Public Admin., New York, 1937.

13 URWICK, L. The elements of administration. Harper \& Bros.: New York, 1943.

14 KOONTZ, H. \& O'DONNEL, C. Management, Sixth Edition, McGraw-Hill: New York, 1976.

is SIMON, H.A. Models of man, social and rational. John Wiley \& Sons: New York, 1957.

16 MARCH, J.G. \& SIMON, H.A. Organizations. John Wiley \& Sons: New York, 1958.

17 CYERT, R.M. \& MARCH, J.G. A behavioral theory of the firm. Prentice-Hall Inc.: Englewood Cliffs, New Jersey, 1963.

18 MINTZBERG, H. The nature of managerial work. Harper \& Row: New York, 1973.

19 ARGYRIS, C. Personality and organization. Harper \& Bros.: New York, 1957.

20 BENNIS, W.G. Changing organizations. McGraw-Hill: New York, 1966.

21 BRAY, D.W. Discussant's comments. Personnel Psychol. 1970, 23:213.

22 RUBIN, J.Z. \& BROWN, B.R. Social psychology of bargaining and negotiation. Academic Press: New York, 1975.

23 COTGROVE, S. \& BOX, S. Science, industry and society. George, Allen \& Urwin: London, 1970.

24 SOFER, C. Men in mid-career: A study of British managers and technical specialists. Cambridge Univ. Press: London, 1970.

25 SCOTT, W.H. Orientation of specialists in a continuous process plant. J. Industr. Rel. 1974, 16(3): 223 - 229.

26 LANSBURY, R. Work Attitudes and Career Orientations among Management Specialists. J. Mgmt Studies, 1976, XIII(1): 32 - 48.

27 SCHEIN, Edgar H. Career dynamics: Matching individuals and organizations. Addison-Wesley: Reading, Massachusetts, 1978. 